\title{
Integrated Water Resources Management: A Case Study for Barind Area, Bangladesh
}

\author{
Md. Tarikul Islam ${ }^{1}$, Prof. Dr. M. Monowar Hossain², Dr. AFM Afzal Hossain ${ }^{3}$ \\ ${ }^{I}$ Senior Specialist, Institute of Water Modelling (IWM), Bangladesh \\ ${ }^{2}$ Executive Director, Institute of Water Modelling (IWM), Bangladesh \\ ${ }^{3}$ Deputy Executive Director ( $\left.P \& D\right)$, Institute of Water Modelling (IWM), Bangladesh
}

\begin{abstract}
The objective of this paper is to review the state of art on integrated water resources management (IWRM) approaches for sustainable irrigation at the basin scale under semi-arid and arid climatic conditions, with main emphasis in Barind area where Surface water irrigation has not been developed satisfactorily due to its limited availability and undulated topography. As IWRM is an interdisciplinary approach and used for different objectives, the main emphasis is given to IWRM approaches for sustainable irrigation and their environmental aspects. In general integrated approaches in Bangladesh are scarce. Groundwater is the main source of irrigation as well as for domestic and industrial purposes in Barind area. In recent years, lowering of groundwater table is observed in some areas of the region. Lowering of groundwater table during dry months creates problems in the operation of STWs and hand tubewells. In some places of Tanore Upazila, declining trend of groundwater level also observed. In the next 25 years, food demand of the country is expected to increase by $29 \%$ which will require increased cropping intensity. In absence of major surface water diversion, added pressure on groundwater will lead to further depletion of the sources. Rivers being recharged from groundwater causing a major natural loss of groundwater through Mahananda and the Ganges river. Reduction of surface water flows and lowering of groundwater table combined with climate change will aggravate the existing water scarcity problem. All these have compounded the sustainable management of water in this area. To overcome this complexity, an integrated water resources management (IWRM) is necessary. Upazila wise potential resource as well as usable resource, present and future demand for expanded irrigation coverage, number of DTW, surface water availability, impact of conserving surface water on kharies have been assessed for the study area which is very important for IWRM.
\end{abstract}

Keywords: IWRM, Drought, Climate Change, Declining trend of Groundwater, Sustainable Irrigation, otential Recharge

\section{Introduction}

Integrated water resources management (IWRM) was defined by the Global Water Partnership (GWP, 2000) as "a process which promotes the coordinated development and management of water, land and related resources, in order to maximize the resultant economic and social welfare in an equitable manner without compromising the sustainability of vital ecosystems."

Currently, one-third of the world's population is living in countries and regions of water resources limitation (Bates, et al., 2008). Because of limited water availability imposing strong restrictions on natural and human systems, the management of water resources has become an urgent issue in semiarid and arid regions. Generally, when the demand of water has reached the limits that the natural system can provide, water shortage can become a major obstacle to social and economic development for one region (Bronster et al., 2000; Li et al., 2006). Therefore, these issues have forced planners to contemplate and propose ever more comprehensive, complex, and ambitious plans for water resources systems in the semiarid and arid regions (Li et al., 2008).

Different studies have documented that groundwater level declined substantially during the last decade causing threat to the sustainability of water use for irrigation in this region and impacting upon other sectors too (Jahan et al. 2010). Due to lack of proper knowledge, indiscriminate installation of pumps and non-availability of modern technologies, farmers inappropriately lift water without caring ground sources. These impacts upon interlinked sources of water table which is declining alarmingly in many areas of Bangladesh. Although the groundwater dominates the total irrigated area, its sustainability is at risk in terms of quantity in the northwest region (Simonovic 1997; Shahid 2011). Frequent shortage of water in the region has had impacts that can be ranged as economical, social and environmental (Takara and Ikebuchi, 1997; Sajjan et al. 2002; Dey et al. 2011).

A recent study shows that groundwater level in some areas falls between 5-10 $\mathrm{m}$ in dry season and most of the tubewells fail to lift sufficient water (Dey and Ali 2010). Researchers and policymakers are advocating sustainable development as the best approach to today's and future water problems (Loucks2000; Cai X et al. 2001). With groundwater development, fluctuations will amplify; but as long as rainfall is managed 
to recharge aquifers, and proactive water saving strategies are put in place, a steady and sustainable state can be achieved (IWMI 2010). In mainstream irrigation thinking, groundwater recharge is considered as a by-product of flow irrigation, but in today's world, groundwater recharge needs to be understood on its first emergency for making groundwater sustainable integrating all possible options (IWMI 2010).

Hydrologic model was a useful tool for water resources management (Sahoo et al., 2006). Previously, many lumped hydrologic models were developed to investigate watershed hydrology. With a low data requirement, these lumped catchment models could reflect runoff dynamics and water balance in water resource management systems. However, the lumped models assumed the study watershed as a spatially homogeneous region, and the spatial heterogeneity of the climate variable and land surface was not considered (Bronster et al., 2000).

Consequently, several distributed and semi-distributed hydrological models were developed in response to the aforementioned challenges (Apul et al., 2005). For example, Refsgaard (1997) integrated MIKE SHE, MIKE 11, MIKE 21, and DAISY to study the environmental assessment in connection with the Gabcikovo hydropower scheme. Sahoo et al. (2006) used the physically distributed hydrological modeling system (MIKE SHE) to study the watershed response to storm events within the Manoa-Palolo stream system on the island of Oahu, Hawaii. IWM (2005, 2006 and 2009) used the physically distributed hydrological modeling system (MIKE SHE \& MIKE 11) for the assessment of potential groundwater and surface water resources. The primary advantage of the distributed hydrological models was enabled to reflect the spatial variations for characteristics of watershed (e.g., rainfall, topography, soil type, and land use) (Refsgaard, 1997). However, higher data requirement became a main obstacle on extensively applying these models to practical problems.

Both the Poverty Reduction Strategy (PRS) and Millennium Development Goal (MDG) of the Government of Bangladesh attached priority to increase agricultural production. In this backdrop, Barind Multipurpose Development Authority (BMDA) undertook a programme entitled "Groundwater Resources Study and Decision Support System Development of Rajshahi, Naogaon, Chapai Nawabganj, Pabna, and Natore Districts and also Remaining Districts (Except Thakurgaon, Panchagarh, Dinajpur \& Joypurhat Districts) of Rajshahi Division Through Mathematical Model Study for Barind Integrated Area

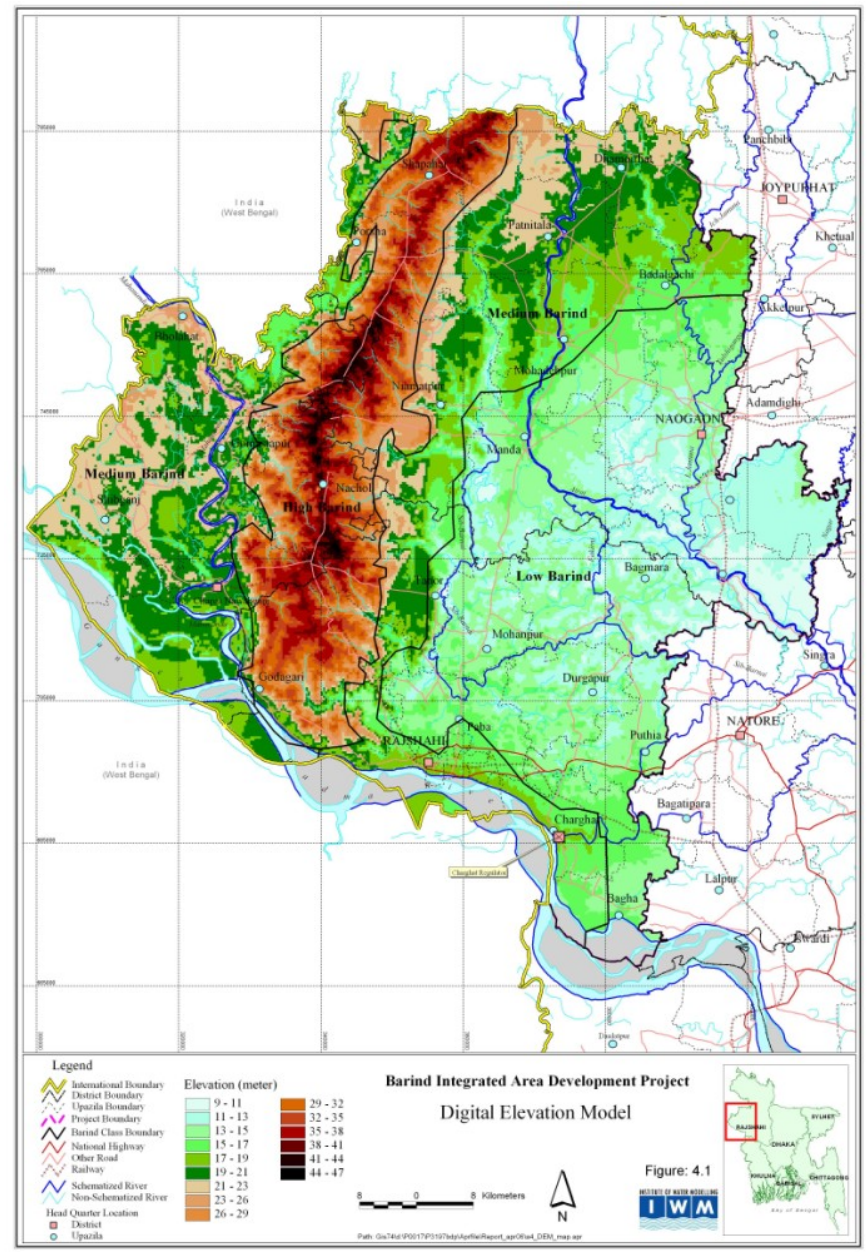

Figure 1: Study Area

Development Project, Phase-III". Under this project, IWM (2012) carried out the study.

The study area comprised of 25 Upazilas of Rajshahi, Chapai Nawabganj and Naogaon District (Figure 1) of Bangladesh and situated in the Ganges Basin. The gross area of the project is about 7,50,000 ha and net cultivable area is $595760 \mathrm{ha}$. The annual rainfall varies from $1250 \mathrm{~mm}$ to $2000 \mathrm{~mm}$ (IWM, 2006). During dry season, most of the ponds and tanks have become derelict creating shortage of water for both domestic and livestock population. Groundwater is the main source of irrigation and other uses using a large number of deep tube well (DTW) and shallow tube well (STW) both by public and private initiatives. Operation of a few thousand DTWs by BMDA and STWs by private owners for irrigation during dry period creates problem for operation of hand tubewells and dug wells. Deficit of rainfall is one of the main reasons for occurring drought in Barind area. Drought is pivoting factor for crop production in this area. Due to drought, frequent damage of crops area occurred in this area.

Climate change is the largest mechanism of global change. It will have pronounced impact on dry season water availability and short period of intensive rain in the wet season causing devastating floods. In 
recent year, it has been observed that climate is becoming more variable with greater occurrence of extreme events in this area. This will encourage the upstream countries to divert more surface water leaving a gloomy picture of prolonged drought with dry wells at many places of the region. Reduction of surface water and lowering of groundwater table combined with climate change will aggravate the existing water scarcity problem.

\subsection{Rational for Groundwater Use}

Though surface water is available at the outfall of the Mohananda river into the Ganges and in the Ganges River, large pumping plants are required for pumping water from the river. Moreover the water levels of the rivers in some reaches go down beyond the suction limit of low lift pumps becoming the problems of pumping from river. Moreover, the undulated topography of the area is not suitable for gravity irrigation. However, pumping from the rivers and conserving water by small water control structures are being practiced for limited surface water irrigation. Main dependence for irrigation is on ground water. Groundwater is being extracted for irrigation mainly by DTW and STW. There are about 8,955 DTW and 97,669 STW in Barind area (BADC, 2010).

After development of groundwater, irrigation coverage and agricultural yield in the area has significantly been increased as well as the cropping pattern has also been changed. Now a days Rabi cultivation season is also known as main irrigation season. However, impact of groundwater use has not been well monitored.

\subsection{Policy Statement for Groundwater Use}

The government policies that have direct relevance with use of groundwater are mainly the National Water Policy (NWPo) and National Agricultural Policy (NAP). In the context of water use, the objectives of the NWPo are to promote agricultural growth through development of groundwater along with surface water. The main elements of Government policy for use of water are to (i) encourage and promote continued development of minor irrigation without affecting drinking water supplies, (ii) encourage future groundwater development for irrigation by both the public and the private sectors, (iii) improve resource utilization through conjunctive use of all forms of surface water and groundwater for irrigation, (iv) strengthen systems for monitoring water use, water quality and groundwater recharge. (v) strengthen crop diversification programmes for efficient water utilisation, (vi) develop and promote water management techniques to prevent wastage and generate efficiency of water and energy use and (vii) produce skilled professionals for water management.

Recently Government has approved the Poverty Reduction Strategic Paper (PRSP) that provides the guideline to achieve the Millennium Development Goals (MDG). In the PRSP, among others, due emphasis has also been given on the rational and productive utilization of the water resources. The main elements of the PRSP as stated in Policy Matrix which have relevance with the efficient and productive use of water includes, among others (i) create additional irrigation facilities utilizing surface water resource where justified, (ii) ensure conjunctive use of surface and groundwater in existing Command Area Development Projects, (iii) monitor quality and quantity of groundwater on regular basis, (iv) augment surface water in rivers, creeks and khals by constructing barrage, rubber dam and water control structures and (v) promote community participation in multipurpose use of water.

\section{Approach and Methodology}

For sustainable management of scarce water resources and to mitigate the impact of drought, integrated water resources management (IWRM) is needed applying technically based procedures to assess the hydrologic and environmental consequences of different water resource management strategies. An attempt has been made in this paper to evaluate the existing condition of groundwater and to assess the possible effects and impacts of drought on groundwater in Barind area with focus on appropriate technologies for assessing hydrologic and environmental consequences of IWRM. Effective management strategy for sustainable use of groundwater resources under complex situation also has been tried to illuminate in this paper.

The MIKE SHE model is a physical distributed hydrological modeling system covering the entire land phase of the hydrological cycle (Abbott et al., 1986). The model consists of five modules: overland flow, evapotranspiration, unsaturated flow, saturated flow and channel flow modules (DHI, 1999). The saturated flow that is allowed for a fully three-dimensional (3D) way is described by the Darcy equation and solved by the iterative implicit finite difference technique. 3D finite difference method is used to simulate the 3D saturated flow in saturated porous media.

$$
\frac{\partial}{\partial x}\left(K_{x x} \frac{\partial h}{\partial x}\right)+\mid \frac{\partial}{\partial y}\left(K_{y y} \frac{\partial h}{\partial y}\right)+\frac{\partial}{\partial z}\left(K_{z z} \frac{\partial h}{\partial z}\right)-Q=S \frac{\partial h}{\partial t}
$$

where $\mathrm{K}_{\mathrm{xx}}, \mathrm{K}_{\mathrm{yy}}$, and $\mathrm{K}_{\mathrm{zz}}$ are the hydraulic conductivity along the $\mathrm{x}, \mathrm{y}$, and $\mathrm{z}$ directions. The $\mathrm{h}$ is the hydraulic head, Q represents the source=sink terms, and $\mathrm{S}$ is the specific storage coefficient. The channel flow is calculated by the one-dimensional simulation using the full dynamic Saint-Venant equations. The coupling between MIKE SHE and MIKE 11 is made via river links. 
In order to achieve the study objectives, IWM (2012) developed an integrated gw-sw model for the study area. The models developed under this study are based on MIKE-11 (DHI, 1999) for the simulation of flows in rivers, irrigation systems, channels and other water bodies and MIKE-SHE (DHI, 1999) for groundwater model. All the major river systems were included in surface water model while updated topographic features, hydro-geological setting, aquifer properties, DEM, land use pattern, irrigation abstractions were incorporated in groundwater model. Both the models were coupled through MIKE SHE and calibration as well as validation was done. The validated model was used to simulate various options and to assess the resources.

\section{Results and Discussions}

Considering lithological variations and groundwater flow capacity, hydro-stratigraphic units of the study area (upto $80 \mathrm{~m}$ depth) have been defined as Clay Top, Upper Aquifer, Clay Middle, Lower Aquifer and Clay Bottom (Figure 2). It reveals from the analysis that within the studied depth upper aquifer and lower aquifer is interconnected and the clay middle is not continuous. In fact there is only one aquifer in the study area. The main aquifer, in most of the area is either semi-confined or leaky. Recharge to the aquifer is predominantly derived from deep percolation of rain and flood water. Lateral contributions from rivers comprise only a small percentage $0.04 \%$ (MPO, 1987) of total potential recharge.

Analysis reveals that in high barind area, specific yield varies from 0.01 to 0.06 , while in low barind area, it varies from 0.06 to 0.30 . Low specific yield will cause excessive drawdown in tubewell for high abstraction rates. In high Barind area, hydraulic conductivity varies from $10 \mathrm{~m} /$ day and $20 \mathrm{~m} /$ day whereas in low barind area it varies from $40 \mathrm{~m} /$ day to 70 $\mathrm{m} /$ day. In high barind area, transmissivity is lower than $1000 \mathrm{~m}^{2} /$ day whereas in low barind area it is higher than $1000 \mathrm{~m}^{2} /$ day. Highly transmissivity aquifer material indicates excellent opportunity for sustainable groundwater development in the area.

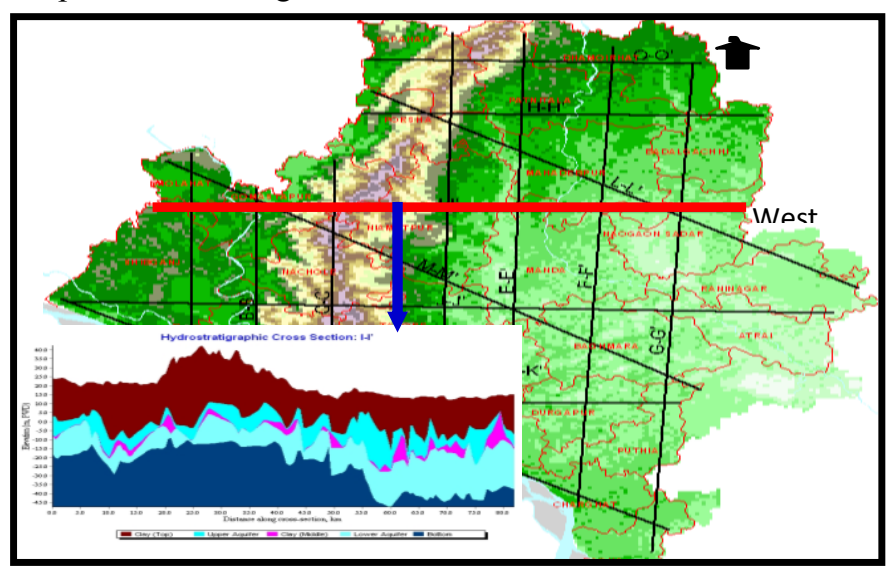

Figure 2: Sample Plot of Hydro-Stratigraphic Cross

Hydrographs of observed groundwater tables show that the maximum and minimum depth to groundwater table occurs at the end of April and end of October respectively. In some places, depth to groundwater table goes below 7.0 to $25.0 \mathrm{~m}$. Suction mode tubewells do not operate in the areas. However, during the peak time of recharge, groundwater table almost regains to its original positions except some places of Tanore. It can be seen from Figure 3 that groundwater is declining at some places of Tanore. In these areas, recharge is less compared to the total abstractions. Decline of groundwater table is mainly occurred due to higher abstraction round the year. In order to avoid this alarming situation groundwater abstraction should be controlled in that area.

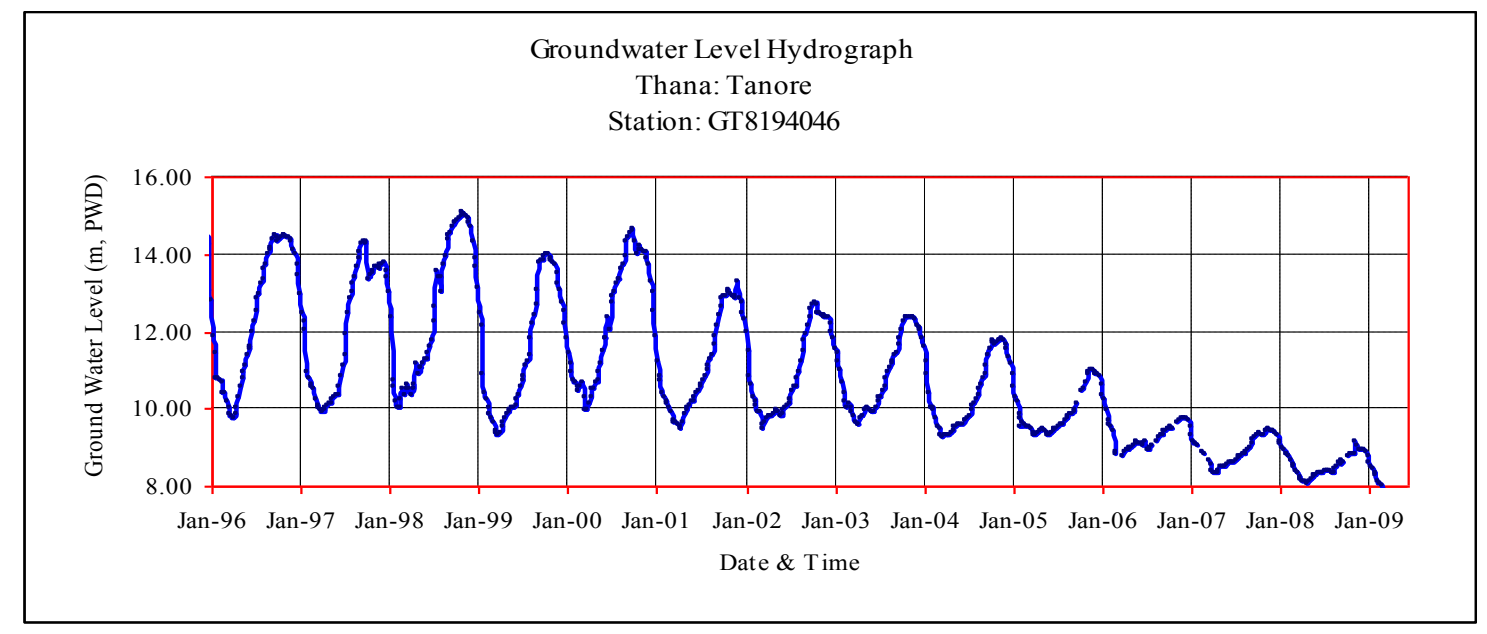

Figure 3: Declining Groundwater Trend in Tanore 
The current water management plans are mostly based on existing knowledge and sparsely aims at optimum use of precious resources. An improved understanding of the hydrologic processes that determine the resource and movement of water in this region is critical to the development of effective strategies for sustainable development water management. The management strategy of groundwater resources depends on the following aspects:

- Assessment of availability and requirements of water resources;

- Understanding the recharge mechanism;

- Identification of scope for future irrigation expansion based on water availability;

- Development of Groundwater Monitoring System;

- Estimation required number of Deep Tubewell;

IWM (2012) carried out the groundwater model study for optimum utilization of available water resources. For the study area, the Upazila wise estimated potential recharge, usable recharge which is $75 \%$ of potential recharge, abstraction and remaining water is given in Table 1 (IWM, 2012).

Table 1: Upazilawise Groundwater Resources

\begin{tabular}{|c|c|c|c|c|c|c|}
\hline SL No. & District & Upazila & Potential Recharge (mm) & $\begin{array}{l}\text { Usable Recharge } \\
(\mathrm{mm})\end{array}$ & $\begin{array}{l}\text { Requirement (mm) } \\
\text { in } 2010\end{array}$ & $\begin{array}{l}\text { Remaining Water } \\
(\mathrm{mm}) \text { in } 2010\end{array}$ \\
\hline 1 & \multirow{11}{*}{ Naogaon } & Atrai & 611 & 458 & 407 & 51 \\
\hline 2 & & Badalgachi & 640 & 480 & 348 & 132 \\
\hline 3 & & Dhamoirhat & 599 & 449 & 535 & -86 \\
\hline 4 & & Mahadebpur & 486 & 365 & 335 & 30 \\
\hline 5 & & Manda & 619 & 464 & 263 & 201 \\
\hline 6 & & Patnitala & 435 & 326 & 294 & 30 \\
\hline 7 & & Porsha & 396 & 297 & 152 & 145 \\
\hline 8 & & Naogaon & 635 & 476 & 394 & 82 \\
\hline 9 & & Niamatpur & 449 & 337 & 296 & 41 \\
\hline 10 & & Raninagar & 623 & 467 & 400 & 67 \\
\hline 11 & & Sapahar & 431 & 323 & 200 & 123 \\
\hline 12 & \multirow{9}{*}{ Rajshahi } & Bagha & 452 & 339 & 181 & 158 \\
\hline 13 & & Bagmara & 486 & 365 & 351 & 14 \\
\hline 14 & & Charghat & 498 & 374 & 352 & 22 \\
\hline 15 & & Durgapur & 570 & 428 & 401 & 27 \\
\hline 16 & & Godagari & 414 & 311 & 302 & 9 \\
\hline 17 & & Mohonpur & 415 & 311 & 281 & 30 \\
\hline 18 & & Paba & 547 & 410 & 289 & 121 \\
\hline 19 & & Puthia & 533 & 400 & 390 & 10 \\
\hline 20 & & Tanore & 330 & 248 & 294 & -46 \\
\hline 21 & \multirow{5}{*}{$\begin{array}{l}\text { Chapai } \\
\text { Nawabganj }\end{array}$} & Bholahat & 664 & 498 & 386 & 112 \\
\hline 22 & & Gomastapur & 438 & 329 & 256 & 73 \\
\hline 23 & & Nachole & 467 & 350 & 212 & 138 \\
\hline 24 & & Nawabganj & 590 & 443 & 158 & 285 \\
\hline 25 & & Shibganj & 498 & 374 & 294 & 80 \\
\hline
\end{tabular}

It was estimated for the future scope of irrigation expansion based on water availability and recommended optimum number of tubewell to be installed in future. The study (IWM, 2006) reveals that although the area has groundwater potential, major part of the area, the groundwater table goes below the suction limit which would be more vulnerable due to climate change. The area is suffering from surface water shortage. The study (IWM, 2006) shows that, the area is loosing groundwater to the nearby river Ganges about $13 \mathrm{Mm}^{3}$ in each year. Some part of the area has already been found as groundwater resource constrained zone. So, it is anticipated that situation might become worse in that area with the longer dry season due to the climate change. However, in other areas of Bangladesh, effective management strategy for sustainable use of groundwater resources needs to be developed considering the above aspects. Careful management can avoid problems in over exploitation of resources and environmental degradation of this area.

\subsection{Surface Water Availability}

For the purpose of assessing surface water resources, discharge data were analyzed to estimate the flow event for different return periods. Monthly available resources in the above rivers were also analyzed. Conservation of these resources was considered by construction of rubber dam. For sustainability of river, usable resource was taken as $70 \%$ of the available resources and remaining $30 \%$ as "in-stream flow requirement" in the river. Based on monthly crop water requirement (Boro-Aman) the scopes for surface water based scheme were also estimated. Table 2 shows the scope of surface water development. It is observed that some water resources are available in Atrai and Mohananda while very limited resource is available in SibBarnai river. 
Table 2: Scope of Surface Water Development

\begin{tabular}{|c|c|c|c|c|c|c|}
\hline \multirow{2}{*}{ Location of Rubber Dam } & \multicolumn{6}{|c|}{ Month } \\
\hline & Nov & Dec & Jan & Feb & Mar & Apr \\
\hline \multicolumn{7}{|l|}{ Atrai River, Ch 60.34 km, Atrai R.B } \\
\hline Monthly Available Water $\left(\right.$ million $\mathrm{m}^{3}$ ) & 50.83 & 31.12 & 20.4 & 13.66 & 11.54 & 11.46 \\
\hline Monthly Water Requirement $\left(\mathrm{m}^{3}\right)$ & 0.127 & 0.065 & 0.258 & 0.21 & 0.251 & 0.18 \\
\hline SW development Area $\left(\mathrm{km}^{2}\right)$ based on resources & 400 & 478 & 79 & 65 & 46 & 64 \\
\hline \multicolumn{7}{|l|}{ Mohananda River, Ch 44.90 km, Nawabganj } \\
\hline Monthly Available Water (million $\mathrm{m}^{3}$ ) & 313.16 & 235 & 193 & 136.66 & 99.69 & 70.4 \\
\hline Monthly Water Requirement $\left(\mathrm{m}^{3}\right)$ & 0.127 & 0.039 & 0.254 & 0.21 & 0.254 & 0.181 \\
\hline SW development Area $\left(\mathrm{km}^{2}\right)$ based on resources & 2466 & 6025 & 762 & 651 & 392 & 388 \\
\hline \multicolumn{7}{|l|}{ Sib-Barnai River, Ch 54.75 km, Pearpur } \\
\hline Monthly Available Water (million $\mathrm{m}^{3}$ ) & 8.48 & 0.78 & 0.7 & - & - & - \\
\hline Monthly Water Requirement $\left(\mathrm{m}^{3}\right)$ & 0.131 & 0.039 & 0.258 & 0.21 & 0.258 & 0.18 \\
\hline SW development Area $\left(\mathrm{km}^{2}\right)$ based on resources & 65 & 20 & 3 & - & - & - \\
\hline
\end{tabular}

\subsection{Impact of Environmental Change on Groundwater}

Environmental change compounds the challenges of sustainable groundwater management of this area as it has significant impact on groundwater levels and recharge capacity as well as water demand. Following issues related to global environmental change and its impact on groundwater resources have been discussed below;

\section{Climate Change}

Climate change is strongly affecting many aspects of physical and biological systems, particularly rainfall distributions and increases of temperature. In Bangladesh, recent studies indicate that there is an increasing trend of temperature of about $10 \mathrm{C}$ in May and $0.50 \mathrm{C}$ in November during the 14 year period from 1985 to 1998 (Mirza, 2002). The temperature projection for the 21st century based on climatic models indicate that in South Asia annual mean warming would be about 2.50 C (IPCC, 2007). The combination of shorter duration but more intense rainfall (meaning more runoff and less infiltration) combined with increased evapotranspiration and increased groundwater abstraction will lead to further groundwater depletion in this area.

\section{Land use change}

Land use and land cover change due to increasing population and urbanization is one of the largest mechanisms of global change. In northwest region of Bangladesh, growth of cities and rural settlement has been increased rapidly due to development of infrastructures. Consequently land available for forest and agriculture has been reduced. It is expected that further development of infrastructures will reduce the area of land available for forest and agriculture by some $17 \%$ (NWMP, 2001) over the next 25 years. This land use change will reduce groundwater recharge area leading to groundwater depletion.

\subsection{Exploration for Deeper Aquifer}

After investigation of potential deeper aquifer, a DTW of $248 \mathrm{~m}$ depth was installed at a place where a severe scare of drinking water was observed. Model result was also analyzed (Figure 6) for additional DTW in deeper aquifer in this area. The simulation results of first trial which is for addition 4 DTWs, shows that groundwater level at Saidpur is goes further $24.3 \mathrm{~m}$ from existing conditions. Though groundwater level almost regains its original position but production cost would be higher considerably due to additional draw down. So it would not be feasible to install four additional DTW. Model was simulated for another trial considering 2 additional DTWs in place of 4 with a spacing $2000 \mathrm{~m}$ and observed that it will create additional $6.0 \mathrm{~m}$ drawdown and groundwater

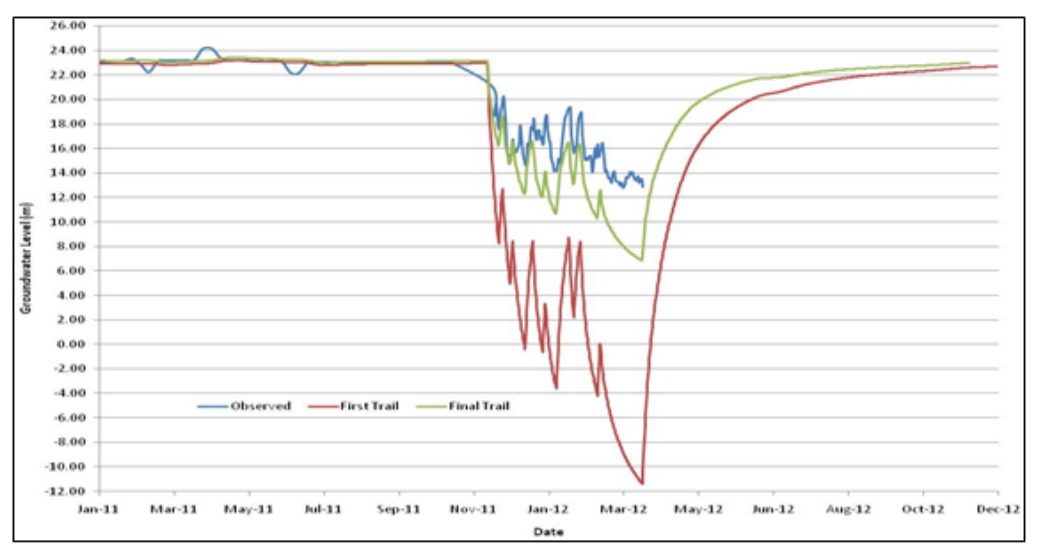

Figure 6: Growndwater level canparison far addition DTW 
level regain its original position. This option is quite feasible. But still it would be needed further detail investigation to know the exact number of additional DTWs as well as resources in deeper aquifer.

\subsection{Necessary Steps for Future Action}

Indiscriminate use of groundwater has already caused some local water scarcity problems in this area. Occurring of drought and environment change will aggravate the water scarcity problems in future. There should have a balance between groundwater recharge and withdrawal. Accordingly, judicious use of surface and groundwater in an integrated water resources management approach is equally important to mitigate the impact of drought. It has been observed from a model study (IWM, 2006) that sufficient rainwater in kharies can be conserved by retention structures. Supplementary irrigation is possible using this water. In addition, groundwater recharge also increases by conserving rainwater in kharies. In view of that, Sarmongla khal (Figure 5) is being used for conserving rain and surface water. However, it is suggested to utilize all kharies in Barind area for conserving rainwater.

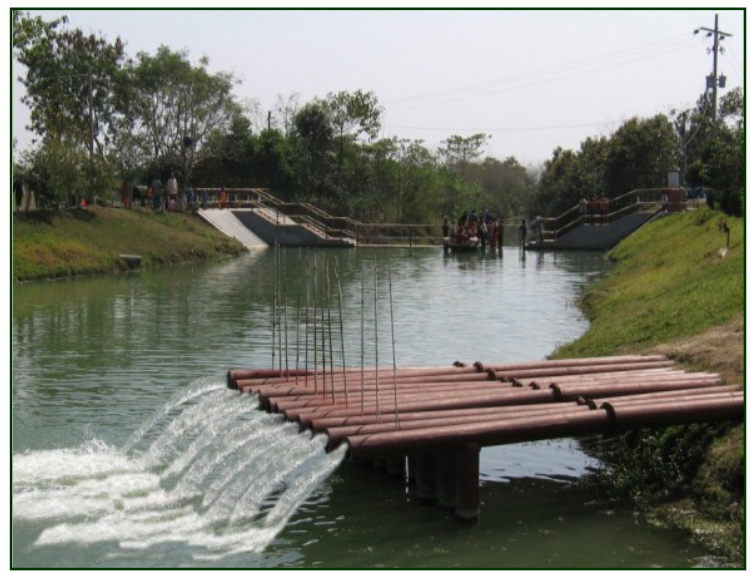

Figure 5: Use of Surface and Rain Water for Irrigation

\section{Conclusion}

Earlier Barind area was a drought prone area and was being desertification due to shortage of surface water and less rainfall. But in recent years, this has been turned into a green due to development of groundwater and surface water for irrigation in an integrated approach. Crops are grown almost everywhere and farming practices have strongly influenced the present vegetation. However, impact of groundwater use should be monitored and it should be used judicially without creating environmental hazards. In Barind area, the problems that are being faced related to water availability, use, control and management are not new. In this regard, conjunctive use of surface and groundwater, development of a monitoring system and finally regional cooperation is essential. For sustainable development of Barind area and to mitigate the impact of drought, a number of mitigations have been worked out among which some of them are already being practiced. Those are: i) rainwater harvesting through construction of cross dam on different Kharies in Barind area, ii) introduce less water consuming crops through crop diversification, iii) introduce of alternate wet and dry (AWD) method for irrigation to reduce water consumption, iv) promote surface water irrigation where and when possible, v) introduce artificial recharge by installation of recharge well, vi) implementation of North-Rajshahi irrigation project and vii) implementation of Ganges Barrage for maintaining a required pond level in different rivers like Ganges, Baral and Mahanda etc.

\section{Acknowledgements}

This study was done by Institute of Water Modelling (IWM) under Barind Multipurpose Development Authority (BMDA) supported by GoB Fund. The authors are grateful to the editors and the anonymous reviewers for their insightful comments and suggestions.

\section{References}

[1] GWP. 2000. Integrated Water Resources Management. TAC Background Papers No. 4, Global Water Partnership: Stockholm. 67 p

[2] Bates, B.C., Kundzewicz, Z.W., Wu, S. and Palutikof, J.P. (2008): Climate Change and Water. Technical Paper of the Intergovernmental Panel on Climate Change, IPCC Secretariat, Geneva. 8.

[3] Bronster, A., Jaegr, A., Ciintner, A., Hauschild, M., Doll, P., and Krol, M. (2000). Integrated modeling of water availability and water use in the semi-arid northeast of Brazil. Phys. Chem. Earth B 25, 227.

[4] Li, Y.P., Huang, G.H., and Nie, S.L. (2006). An interval-parameter multistage stochastic programming model for water resources management under uncertainty. Adv. Water Resour. 29,776.

[5] Li, Y.P., Huang, G.H., Yang, Z.F., and Nie, S.L. (2008). Interval-fuzzy multistage programming for water resources management under uncertainty. Resour. Conserv. Recycl. 52,800.

[6] Jahan CS, MazumderQH, Islam ATMM and Adham MI (August 2010). Impact of irrigation in barind area, northwest Bangladeshan evaluation based on the meteorological parameters and fluctuation trend in groundwater table. Journal Geological Society of India. Vol. 76, pp. $134-142$

[7] Simonovic SP (1997). Risk in sustainable water resources management. In: Sustainability of water resources under increasing uncertainties. IAHS Pub. No. 240

[8] Shahid S (2011). Impact of climate change on irrigation water demand of dry season Boro rice In northwest Bangladesh. Climatic Change 105, P: 433-453

[9] Takara K and Ikebuchi S (1997). Japan's 1994 drought in terms of drought duration curve. proc. of the fifth symposium of Water Resources; P: 467-77. 
[10] Sajjan AK, Muhammed A Bhuiyan and Nepal C Dey (2002). Impact of 1994-95 drought in the northwest of Bangladesh through questionnaire survey. In proc. of the 2nd annual paper meet of Ag. Eng. Division, Institution of Engineers, Bangladesh; P: 31-5

[11] Dey NC, Alam M S Sajjan A K, Bhuiyan M A, Ghose L, Ibaraki Y and Karim F (2011). Assessing environmental and health impact of drought in the northwest Bangladesh. Journal of Environmental Science \& Natural Resources. Vol. 4, No. 2, pp. 89-97

[12] Dey NC and Ali ARM M (2010). Changes in the use of safe water and water safety measures in WASH intervention areas of Bangladesh: a midline assessment. BRAC-RED Working Paper 27

[13] Loucks D P (2000). Sustainable water resources management. Water International 25(1); P.3-11.

[14] Cai X, Daene C McKinney and Mark W Rosegrant (2001). Sustainability analysis for irrigation water management: concepts, methodology, and application to the Aral Sea region: International Food Policy Research Institute, NY, USA, EPTD Discussion Paper No. 86 CGW

[15] International Water Management Institute (IWMI) (2010). Water policy brief banking of groundwater in times of change. Issue 32. www.iwmi.cgiar.org/Publications/Water Policy Briefs/PDF/WPB32.pdf)

[16] Sahoo, G.B., Ray, C., De Carlo, E.H. (2006). Calibration and validation of a physically distributed hydrological model, MIKE SHE, to predict stream flow at high frequency in a flashy mountainous Hawaii stream. J. Hydrol. 327, 94.

[17] Apul, D., Gardner, K., and Eifhmy, T. (2005). Probabilistic modeling of one-dimensional water movement and leaching from highway embankments containing secondary materials.Environ. Eng. Sci. 22, 156.

[18] Refsgaard, J.C. (1997). Parameterisation, calibration and validation of distributed hydrological models. J. Hydrol. 198, 69.

[19] IWM (2005). Groundwater Management and Zoning Study for repair and Rehabilitation of Deep Tubewell Project in Greater Dinajpur District under Post Drought Agricultural Rehabilitation Programme, December 2005, Final Report, Volume 1.

[20] IWM (2006). Groundwater Resources Study for Deep Tube Well Installation Project in Barind Area, Final Report, Volume 1.

[21] IWM (2009). Groundwater Resource Study and Decision Support System Development of Thakurgaon, Panchagarh, Dinajpur and Joypurhat Districts through Mathematical Model Study, Final Report, Volume-I.

[22] Institute of Water Modelling (IWM, 2012): Groundwater Resources Study and Decision Support System Development of Rajshahi, Naogaon, Chapai Nawabganj, Pabna, and Natore Districts and also Remaining Districts (Except Thakurgaon, Panchagarh, Dinajpur \& Joypurhat Districts) of Rajshahi Division Through Mathematical Model Study for Barind Integrated Area Development Project, Phase-III, Final Report, Volume-I.

[23] BADC (2008). Minor Irrigation Survey Report

[24] Abbott, M.B., Bathurst, J.C., Cunge, J.A., Ocinnell, P.E., and Rasmussen, J. (1986). An introduction to the European hydrological system - systeme hydrologique Europeen, She. 2. Structure of a physically-based, distributed modeling system. J. Hydrol. 87, 61.

[25] DHI (1999). MIKE SHE User Manual- Hydrological Modelling System for Groundwater.

[26] DHI (1999). MIKE 11 User Manual - a Modelling system for Rivers and Channels.

[27] Mirza, M.Q., 2002: Global warming and changes in the probability of occurrence of floods in Bangladesh and implications. Global Environ. Chang., 12, 127-138

[28] IPCC, 2007: Climate Change 2007: The Scientific Basis. Contribution of Working Group II to the Assessment Report of the Intergovernmental Panel on Climate Change [Houghton, J.T, et al. (eds)]

[29] WARPO, 2001: National Water Management Plan, Volume 2, Main Report. 